\title{
Om betydningen af den senmoderne danske (K/M/L)-va- riation som henholdsvis Pige-sprog og Drenge-sprog
}

\author{
Tore Kristiansen
}

Ved Sprogforandringscentret (DGCSS) ved Københavns Universitet gennemfører vi ret omfattende undersøgelser af unge menneskers holdninger til den sproglige variation der er en del af deres hverdag. Hvis vi omtaler denne variation som (K)-farvning, (M)farvning og (L)-farvning af dansk 'standardsprog', viser vores resultater at (M)-farvet sprogbrug kommer bedst ud når vurderingen gælder 'dynamiske' værdier ('spændende', 'tjekket' o.l.), mens (K)-farvet sprogbrug klarer sig lige så godt eller bedre når det drejer sig om 'superiore' værdier ('klog', 'seriøs' o.l.). (L)farvning nedvurderes generelt og stærkt i forhold til både (M)og (K)-farvning. Denne artikel ser nærmere på hvordan taler-køn spiller ind. (M)-farvning vurderes gennemgående og konsistent mere positivt som Drenge-sprog end som Pige-sprog. I hovedsag vurderes (K)-Drenge mere positivt end (K)-Piger mht. 'superiore' værdier, men mere negativt mht. 'dynamiske' værdier; (K)Drenge nedvurderes især som 'kedelige' og 'utjekkede'. Taler$k ø n n e t s$ betydning for vurderingen af (L)-farvning varierer mere de undersøgte steder imellem.

Når mennesker der ikke kender hinanden, mødes, dannes der gensidige førsteindtryk på grundlag af en række stil-signaler: mimik, tøj, frisure, stemme, kropsholdning, gangart, sprogbrug, you name it. Mange aspekter ved sprogbrugen spiller væsentligt ind. Hvis vi fjernede alle andre signaler, kunne vi ikke undgå stadig at have sproget til at afsløre eller fortælle hvem vi er eller gerne vil fremstå som.

Disse førsteindtryk er stereotypier, psykologiske 'båse' vi sætter hinanden i. Båsene er i høj grad baseret på sociale værdier og værditilskrivning, på sociale sammenligninger og vurderinger. Det er nok grunden til at 'stereotyp' i dagligsproget er et fyord; den moralske pegefinger siger at vi skal passe på ikke at 'skære alle over én kam'. Vi skal behandle hinanden som individer, ikke som gruppemedlemmer. 


\section{Tore Kristiansen}

Det gør vi som regel også, efterhånden som vi bliver bedre kendt og ved mere om hvem vi hver især "egentlig er" (gåseøjnene signalerer naturligvis at jeg nødig vil sættes i bås som essentialist). Men for at vi skal få en første orden på nye indtryk, er fordomme - allerede foreliggende domme - en simpel psykologisk nødvendighed. Og det ligger i sagens natur at vi skal være relativt fælles om disse domme, og at de skal være relativt stabile. Ellers fungerer de(t) ikke.

Ved Danmarks Grundforskningsfonds Center for Sociolingvistiske Sprogforandringsstudier (DGCSS) (http://dgcss.hum.ku.dk) indgår studiet af disse makrosociale ideologiske strukturer som et væsentligt bidrag til centrets arbejde med at beskrive og forstå Danmarks vej fra dialektsamfund til standardsprogsamfund i løbet af det 20. århundrede. Vi foretager ret omfattende undersøgelser af de stereotypier der knyttes til den dominerende sproglige variation blandt dagens unge danskere (se Kristiansen 2009) - en variation vi omtaler som (K/M/L)-farvning af dansk 'standardsprog' (med reference til termerne KONSERVATIV/MODERNE/LOKAL).

Artiklen begynder med en kort præsentation af det overordnede resultat af disse undersøgelser (afsnit 1), men hovedformålet er først at belyse, på empirisk grundlag, hvorvidt de sprogbrugsrelaterede stereotypier er de samme hvad enten taleren er Pige eller Dreng ${ }^{1}$ - eller om det skulle være sådan at en LOKAL-farvet Dreng vurderes anderledes end en LOKAL-farvet Pige, osv. (afsnit 2).

\section{Masketesten: Stereotypier knyttet til de senmoderne danske ak- sanger}

Det eksperimentelle design der blev brugt til at indsamle dataene, kalder vi for masketesten. Begrebet 'maske' er brugt fordi det er en væsentlig pointe i projektet som helhed at fremkalde underbevidste reaktioner på sprogbrug i tillæg til bevidste holdningstilkendegivelser. Denne forskel inddrages ikke i denne sammenhæng. Men det er på sin plads at understrege at de data der analyseres i det følgende, er indsamlet ved brug af masketest-oplægget. Det vil sige at informanterne reagerede på sprogbrug uden at blive opmærksom på at der var forskelle af dialektal art med i spillet. De 'dialekter' der her er tale om, er i det væsentlige forskellige prosodiske farvninger af dansk (standardsprog). Lad os kalde dem aksanger.

Testen består $\mathrm{i}$ at der afspilles 12 stemmer fra en CD. Stemmerne er unge (16 år gamle), 6 Piger og 6 Drenge. Hver stemme taler i ca. 30 sekunder. Da det vi er interesserede i at undersøge, er informanternes reaktioner på forskelle i udtrykket (aksang-træk), har vi forsøgt 
Om betydningen af den senmoderne danske ...

at kontrollere for indflydelse fra forskelle i indholdet ved at alle svarer frit men nogenlunde enslydende på spørgsmålet: hvad er en god larer? Otte af stemmerne tilhører københavnere, udvalgt (af os forskere) til at repræsentere hhv. en MODERNE aksang (4 stemmer) og en lidt mere KONSERVATIV aksang (4 stemmer). De samme københavnske stemmer blev brugt i alle unders $\varnothing$ gte lokalsamfund. I tillæg afspilledes i lokalsamfundene 4 stemmer (2 Piger og 2 Drenge) der på samme måde var udvalgt til at repræsentere den LOKALE aksang. Som kriterium for at acceptere de indsamlede data som tilkendegivne holdninger over for forskelle $\mathrm{i}$ aksang krævedes det at de 4 stemmer der udgjorde hver af aksangerne, skulle vurderes overvejende ensartet på skalaerne (dvs. ens i forhold til hinanden og forskelligt fra de andre). Dette resultatmønster er gennemgående tilstrækkeligt klart til at vi med sikkerhed

Figur 1. Masketesten: Stemmerne

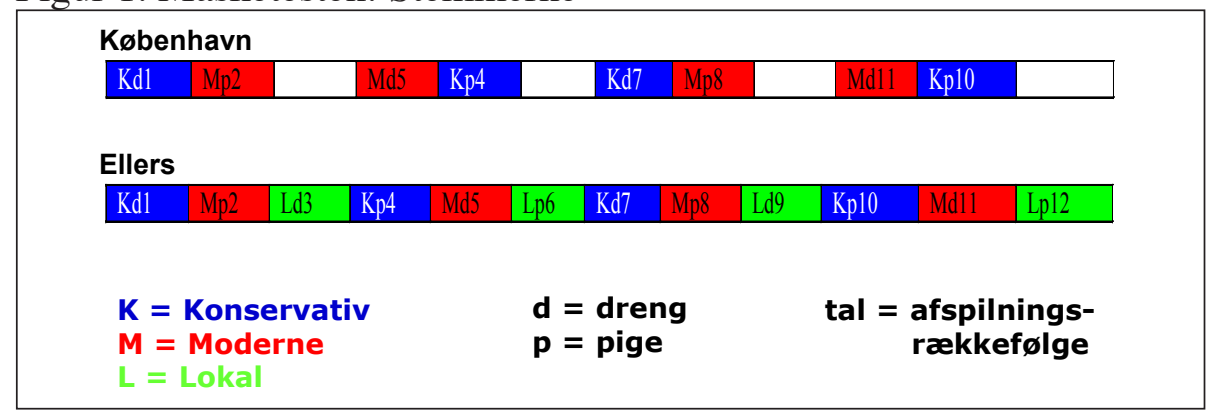

kan sige at det er aksang-forskellene der har været afgørende ved vurderingerne. På dette grundlag er stemme-resultaterne slået sammen til de aksang-resultater der præsenteres i det følgende. Med henblik på at lette oversigten i resultatfremstillingerne bliver aksangerne farvelagt som vist i Figur 1.

Informanterne er elever i 9. klasse (typisk 15 år gamle). De fem undersøgte steder er, opregnet fra øst til vest: København, Næstved, Vissenbjerg, Odder, Vinderup. I tillæg til de fem steder viser Figur 2 også de nærmeste større byer hvad angår Vissenbjerg, Odder og Vinderup, idet de lokale stemmer til testen blev fundet i hhv. Odense, Århus og Holstebro. Grunden var at vi ønskede at teste en hypotese om at disse byer kunne spille en rolle som sproglige normcentre i deres regioner: Vi ville have et indicium for dét hvis de LOKALE stemmer blev vurderet mere positivt end de københavnske. For Næstveds vedkommende regnede vi med at byen i sig selv kunne have potentiale til at stå København imod som sydsjællandsk normcenter. I København repræsenteres det lokale sprog af aksangerne KONSERVATIV og MODERNE. 
Figur 2. Masketesten: Steder og LOKALE stemmer

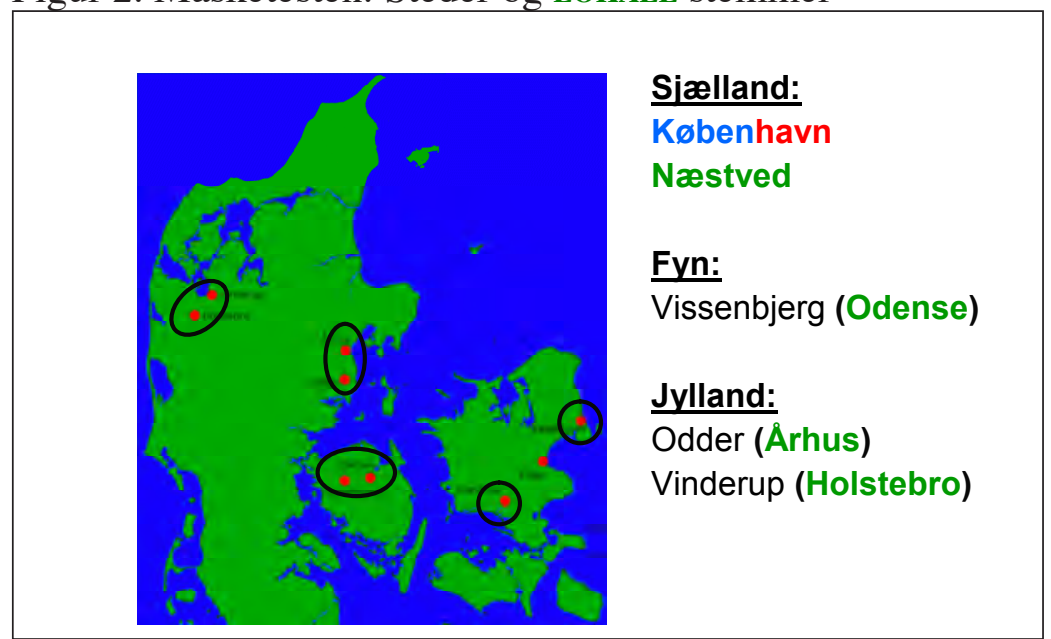

Måleinstrumentet bestod af et hæfte med skemaer, et for hver stemme (person), hvor stemmerne efter tur blev vurderet ved afkrydsning på 7-trinsskalaer mht. de 8 personlighedstræk der fremgår af Figur 3. Vi antager at det giver god mening at sige at alle disse skalaer har en positiv ende (til venstre) og en negativ ende (til højre), hvilket giver os mulighed for dels at lægge skalaer sammen, dels at udtrykke os generelt om hhv. positive og negative vurderinger.

Figur 3. Masketesten: Vurderingsskalaer

\begin{tabular}{|c|c|}
\hline \multicolumn{2}{|c|}{$\begin{array}{l}\text { Person } 1 \\
\text { Hvordan opfatter du denne person? }\end{array}$} \\
\hline målrettet & sløv \\
\hline til at stole på & ikke til at stole på \\
\hline seriøs & ligeglad \\
\hline spændende & kedelig \\
\hline selvsikker & usikker \\
\hline klog & dum \\
\hline flink & usympatisk \\
\hline tjekket & utjekket \\
\hline
\end{tabular}


Om betydningen af den senmoderne danske ...

Figur 4. Vurdering af aksangerne K, M, Li alle 5 samfund

\begin{tabular}{|c|c|c|c|c|c|c|c|c|c|c|c|}
\hline \multicolumn{6}{|c|}{ SUPERIORITET } & \multicolumn{6}{|c|}{ DYNAMIK } \\
\hline 1. Klog & & & & & & 5. Selvsikker & & & & & \\
\hline København & $\mathbf{K}$ & $* * *$ & M & & & København & $\mathbf{M}$ & $* * *$ & $\mathbf{K}$ & & \\
\hline Næstved & $\mathbf{K}$ & $* * *$ & $\mathbf{M}$ & $* * *$ & $\mathbf{L}$ & Næstved & M & $* * *$ & $\mathbf{K}$ & $* * *$ & $\mathbf{L}$ \\
\hline Vissenbjerg & $\mathbf{K}$ & $*$ & M & $* * *$ & $\mathbf{L}$ & Vissenbjerg & $\mathbf{M}$ & $* * *$ & $\mathbf{K}$ & $* * *$ & $\mathbf{L}$ \\
\hline Odder & $\mathbf{K}$ & $* *$ & $\mathbf{M}$ & $* * *$ & $\mathbf{L}$ & Odder & $\mathbf{M}$ & $* * *$ & $\mathbf{K}$ & $* * *$ & $\mathbf{L}$ \\
\hline Vinderup & $\mathbf{K}$ & $* *$ & $\mathbf{M}$ & $* * *$ & $\mathbf{L}$ & Vinderup & $\mathbf{M}$ & $* * *$ & $\mathbf{K}$ & $* * *$ & $\mathbf{L}$ \\
\hline 2. Seriøs & & & & & & 6. Spændende & & & & & \\
\hline København & $\mathbf{K}$ & $* * *$ & $\mathbf{M}$ & & & København & $\mathbf{M}$ & $* * *$ & $\mathbf{K}$ & & \\
\hline Næstved & $\mathbf{K}$ & / & $\mathbf{M}$ & $* * *$ & $\mathbf{L}$ & Næstved & $\mathbf{M}$ & $* * *$ & $\mathbf{K}$ & $* *$ & $\mathbf{L}$ \\
\hline Vissenbjerg & $\mathbf{K}$ & l & $\mathbf{M}$ & $* * *$ & $\mathbf{L}$ & Vissenbjerg & $\mathbf{M}$ & $* * *$ & $\mathbf{K}$ & I & $\mathbf{L}$ \\
\hline Odder & $\mathbf{K}$ & $*$ & M & $* * *$ & $\mathbf{L}$ & Odder & $\mathbf{M}$ & $* * *$ & $\mathbf{K}$ & $* * *$ & $\mathbf{L}$ \\
\hline Vinderup & $\mathbf{K}$ & $* *$ & $\mathbf{M}$ & $* * *$ & $\mathbf{L}$ & Vinderup & $\mathbf{M}$ & $* * *$ & $\mathbf{K}$ & $* *$ & $\mathbf{L}$ \\
\hline 3. Målrettet & & & & & & 7. Tjekket & & & & & \\
\hline København & $\mathbf{K}$ & l & $\mathbf{M}$ & & & København & $\mathbf{M}$ & $* * *$ & $\mathbf{K}$ & & \\
\hline Næstved & M & I & $\mathbf{K}$ & $* * *$ & $\mathbf{L}$ & Næstved & M & $* * *$ & $\mathbf{K}$ & $* *$ & $\mathbf{L}$ \\
\hline Vissenbjerg & M & l & $\mathbf{K}$ & $* * *$ & $\mathbf{L}$ & Vissenbjerg & $\mathbf{M}$ & $* * *$ & $\mathbf{K}$ & l & $\mathbf{L}$ \\
\hline Odder & $\mathbf{K}$ & l & M & $* * *$ & $\mathbf{L}$ & Odder & $\mathbf{M}$ & $* * *$ & $\mathbf{K}$ & $* * *$ & $\mathbf{L}$ \\
\hline Vinderup & $\mathbf{K}$ & / & M & $* * *$ & $\mathbf{L}$ & Vinderup & $\mathbf{M}$ & $* * *$ & $\mathbf{K}$ & $* *$ & $\mathbf{L}$ \\
\hline 4. Til at stole på & & & & & & 8. Flink & & & & & \\
\hline København & $\mathbf{K}$ & l & $\mathbf{M}$ & & & København & $\mathbf{M}$ & $*$ & $\mathbf{K}$ & & \\
\hline Næstved & M & l & $\mathbf{K}$ & $* * *$ & $\mathbf{L}$ & Næstved & $\mathbf{M}$ & $*$ & $\mathbf{K}$ & $* * *$ & $\mathbf{L}$ \\
\hline Vissenbjerg & M & l & $\mathbf{K}$ & $* * *$ & $\mathbf{L}$ & Vissenbjerg & M & l & $\mathbf{K}$ & $*$ & $\mathbf{L}$ \\
\hline Odder & $\mathbf{K}$ & l & M & $* * *$ & $\mathbf{L}$ & Odder & M & $* * *$ & $\mathbf{K}$ & $* * *$ & $\mathbf{L}$ \\
\hline Vinderup & $\mathbf{K}$ & l & M & $* *$ & $\mathbf{L}$ & Vinderup & $\mathbf{M}$ & / & $\mathbf{K}$ & I & $\mathbf{L}$ \\
\hline
\end{tabular}

Wilcoxon Signed Pair Test: $* * *=\mathrm{p}<.001 * * \mathrm{p}<.01 *=\mathrm{p}<.05 \quad /=$ n.s.

Figur 5. Vurderingerne af K, M, Li hvert af samfundene og totalt

\section{KØBENHAVN (N=136)}

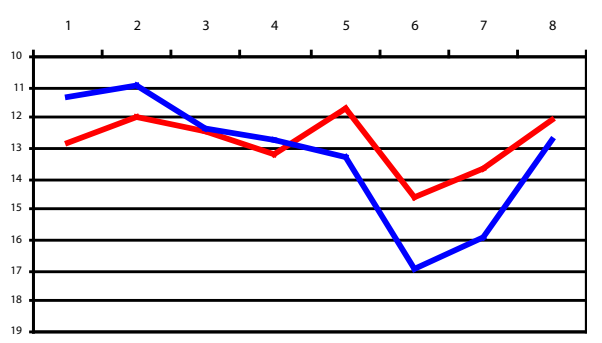

NASTVED $(\mathrm{N}=183)$

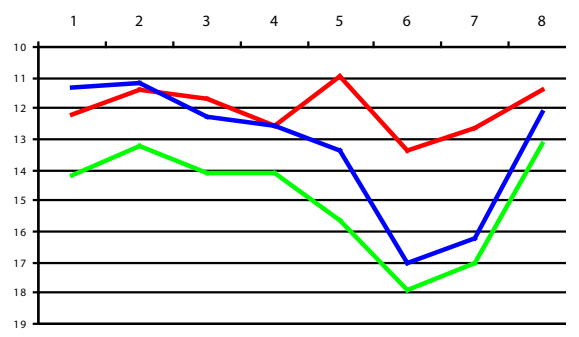


VISSENBJERG $(\mathrm{N}=54)$

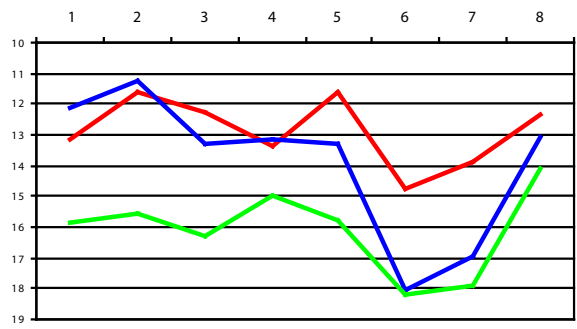

VINDERUP $(\mathrm{N}=85)$

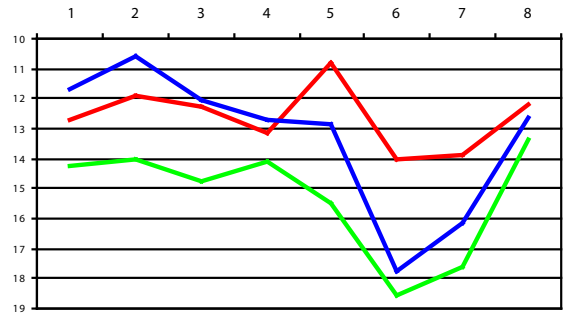

ODDER $(\mathrm{N}=174)$

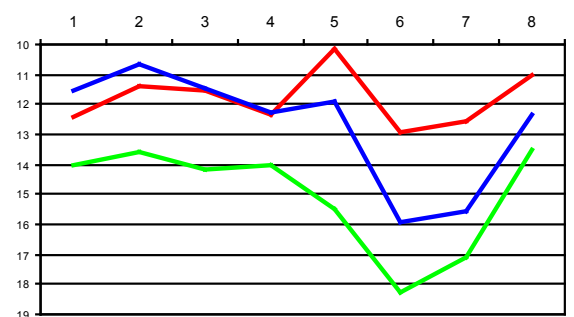

Tallene 10-19 på værdiaksen er fra den 'skala' der fremkommer når vi sammenlægger 4 stemmers værdier på skalaer med 7 trin; den får minimumsværdi 4, maksimumsværdi 28 , og midterværdi 16. Aksangernes gennemsnit på vurderingsskalaerne fås ved at dividere med 4. Lav værdi ( $\varnothing$ verst på aksen) er mere positiv vurdering.

Tallene 1-8 på kategoriaksen står for personlighedstrækkene (se Figur 4).

I Figur 4 ses resultaterne for aksangerne (K), (M) og (L). Hvis vi siger at de værdier fra vurderingsskalaerne der er anført i figuren ('klog', 'seriøs', osv.), repræsenterer den positive ende, kan vi udtrykke os som følger: (L) nedvurderes i sammenligning med (M) og (K) - overalt og på alle skalaer. Når vi sammenligner vurderingerne af $(\mathrm{M}) \mathrm{og}(\mathrm{K})$, ser vi to mønstre: Mht. værdierne 'selvsikker, spændende, tjekket, flink' (i højre halvdel af Figur 4) vurderes (M) mere positivt end (K); mht. værdierne 'klog, seriøs, målrettet, til at stole på' (i venstre halvdel af Figur 4) klarer (K) sig lige godt som eller bedre end (M). Vi kan tale om to vurderingsdimensioner og benævne dem hhv. 'dynamik' og 'superioritet'. Også den beskrevne forskel i vurderingen af $(\mathrm{K})$ og $(\mathrm{M})$ reproduceres ensartet over alt.

Indtrykket af ensartethed bliver endnu mere slående når resultaterne fremstilles i form af grafiske kurver, som vist i Figur 5. De fem 
Om betydningen af den senmoderne danske ...

samfunds 'vurderingsprofiler' ligner hinanden til forveksling. Der eksisterer altså en stærk ideologisk konsensus på nationalt plan blandt unge danskere omkring de sociale stereotypier der er knyttet til de senmoderne danske aksanger. Denne nationale enighed kan umuligt udspringe andre steder fra end København.

\section{Taler-kønnets betydning}

På baggrund af det københavnske hegemoni i det danske sprogholdningsunivers skal vi nu først se på hvordan det københavnske vurderingsmønster mht. 'kønnet' (K/M)-variation ser ud, og dernæst med spænding se på om også dét genfindes i de fire andre samfund, eller om det er et andet. Samtidig ser vi naturligvis også på om taler-kønnet er af betydning for vurderingen af det (L)-farvede sprog.

I udgangspunktet forekommer det ret rimeligt at forestille sig at de stereotype vurderinger der forbindes med $(\mathrm{K} / \mathrm{M} / \mathrm{L})$-variationen, kan være forskellige afhængigt af om aksangerne forekommer i munden på en Pige eller en Dreng. Der findes tidligere danske resultater der peger i den retning (Maegaard 2005). Det forekommer også rimeligt at forestille sig at disse 'køn-og-aksang'-stereotypier kan være forskellige i de forskellige lokalsamfund. For at kunne undersøge dette opererer vi med to Pige-stemmer og to Drenge-stemmer for hver af de tre aksanger (se Figur 1). Afsnittet er inddelt i en beskrivelsesdel (2.1) og en diskussionsdel (2.2).

\subsection{Taler-kфnnets betydning: Vurderingsmønstre}

Figurerne 6-10 viser, for hvert af samfundene i tur og orden, hvordan aksangernes 'kønnede' versioner - dvs. KONSERVATIV, MODERNE Og LOKAL talt af hhv. Drenge og Piger - er blevet vurderet i forhold til hinanden. De vil blive omtalt som (D-k) vs. (P-k), (D-m) vs. (P-m) og (D-l) vs. (P-1). Tallene i figurerne er de 'kønnede' aksangers gennemsnitlige rangorden (ikke gennemsnitsværdier på 7-trinsskalaerne). Jo lavere tal jo mere positiv vurdering. Hvis vi tager resultaterne på skalaen 1.klog i Figur 6 som eksempel, er (D-k) mest positivt vurderet $(2,07)$, fulgt af (D-m) $(2,43),(P-k)(2,45)$ og (P-m) $(3,04)$. Det gælder for alle disse rangordner som helhed, $\mathrm{i}$ alle sprogsamfund, at de er statistisk signifikante (Friedman test; alle $\mathrm{p}<0,001$, bortset fra skalaen 3.målrettet $\mathrm{i}$ København hvor $\mathrm{p}<0,05)$. Forskellen i vurdering af D-P er dernæst signifikanstestet parvis inden for hver aksang (Wilcoxon Signed Pair Test). 


\section{Tore Kristiansen}

Det er resultatet af denne testning der er angivet $\mathrm{i}$ venstre halvdel af figurerne. I højre halvdel er det kønsmønster som fremkommer i signifikanstestningen, fors $\emptyset \mathrm{gt}$ tydeliggjort.

\section{$\underline{\text { København }}$}

Hvis vi først ser på scorerne i den københavnske masketest (Figur 6), er det gennemgående indtryk at Drenge vurderes mere positivt end Piger ganske uafhængigt af aksang. Forskellen er klarere (oftere signifikant) mht. superioritet (skalaerne 1-4) end mht. dynamik (skalaerne 5-8). Det omvendte mønster forekommer på to dynamikskalaer (markeret med gråtoning): De københavnske informanter har vurderet (K)-talende Drenge (D-k), som mere 6.kedelige og 7.utjekkede end (K)-talende Piger (P-k) (signifikant kun i det sidste tilfælde).

Figur 6. København: Vurdering af 'kønnet' (K/M)-variation. Tallene står for gennemsnitlig rangorden. Lavt tal er mere positiv vurdering.

\begin{tabular}{|c|c|c|c|c|c|c|c|}
\hline & \multicolumn{4}{|c|}{ AKSANG } & \multicolumn{3}{|c|}{ Kønsmanster } \\
\hline & Konserv: & ativ & Moderi & & $\mathbf{D}>\mathbf{P}$ & $\mathbf{D}=\mathbf{P}$ & $\mathbf{P}>\mathbf{D}$ \\
\hline 1. Klog & $\begin{array}{r}\mathbf{D}_{2,07} \\
\text { (**) }\end{array}$ & $\begin{array}{l}\mathbf{P} \\
2,45\end{array}$ & $\underset{2,43}{\mathbf{D}} * * *$ & $\begin{array}{l}\mathbf{P} \\
3,04\end{array}$ & $\mathrm{~km}$ & & \\
\hline 2. Seriøs & ${ }_{2,13}{ }^{\text {D }}$ & $\begin{array}{l}\mathbf{P} \\
2,51\end{array}$ & D $_{2,35}$ *** & $\begin{array}{l}\mathbf{P} \\
3,01\end{array}$ & $\mathrm{~km}$ & & \\
\hline $\begin{array}{l}\text { 3. Mål- } \\
\text { rettet }\end{array}$ & $\begin{array}{rr}\mathbf{D} & 1 \\
2,37 & \\
\end{array}$ & $\begin{array}{l}\mathbf{P} \\
2,53\end{array}$ & $\begin{array}{r}\mathbf{D}_{2,34} \\
\end{array}$ & $\begin{array}{l}\mathbf{P} \\
2,76\end{array}$ & $\mathbf{M}$ & k & \\
\hline $\begin{array}{l}\text { 4. Til at } \\
\text { stole på }\end{array}$ & $\underset{2,25}{\text { D }}$ * & $\begin{array}{l}\mathbf{P} \\
2,55\end{array}$ & $\underset{2,35}{\mathbf{D}} * * *$ & $\begin{array}{l}\mathbf{P} \\
2,85\end{array}$ & $\mathrm{~km}$ & & \\
\hline $\begin{array}{l}\text { 5. Selv- } \\
\text { sikker }\end{array}$ & $\underset{2,68}{\mathbf{D}}$ & $\begin{array}{l}\mathbf{P} \\
2,81\end{array}$ & $\underset{2,12}{\mathbf{D}}$ & $\begin{array}{l}\mathbf{P} \\
2,38\end{array}$ & & $\mathrm{~km}$ & \\
\hline $\begin{array}{l}\text { 6.Spænd } \\
\text { ende }\end{array}$ & $\begin{aligned} \mathbf{P} & \text { I } \\
2,73 & \end{aligned}$ & $\begin{array}{l}\text { D } \\
2,95\end{array}$ & $\underset{2,12}{\mathbf{D}} \quad /$ & $\begin{array}{l}\mathbf{P} \\
2,20\end{array}$ & & $\mathrm{k} \mathrm{m}$ & \\
\hline $\begin{array}{l}\text { 7. Tjek- } \\
\text { ket }\end{array}$ & $\underset{2,66}{\mathbf{P}} * * *$ & $\begin{array}{l}\text { D } \\
3,07\end{array}$ & $\begin{aligned} \text { D } & \text { l } \\
2,09 & \end{aligned}$ & $\begin{array}{l}\mathbf{P} \\
2,18\end{array}$ & & $\mathrm{~m}$ & $\mathrm{k}$ \\
\hline 8. Flink & $\begin{array}{rl}\mathbf{D} & 1 \\
2,59 & \end{array}$ & $\begin{array}{l}\mathbf{P} \\
2,64\end{array}$ & $\underset{2,14}{\mathbf{D}} * * *$ & $\begin{array}{l}\mathbf{P} \\
2,63\end{array}$ & $\bar{M}$ & $\bar{k}$ & \\
\hline
\end{tabular}

Wilcoxon Signed Pair Test: $* * *=p<.001 * * \mathrm{p}<.01 *=\mathrm{p}<.05 \quad /=$ n.s. 
Om betydningen af den senmoderne danske ...

Figur 7. Næstved: Vurdering af 'kønnet' (K/M/L)-variation.

Tallene står for gennemsnitlig rangorden. Lavt tal er mere positiv vurdering.

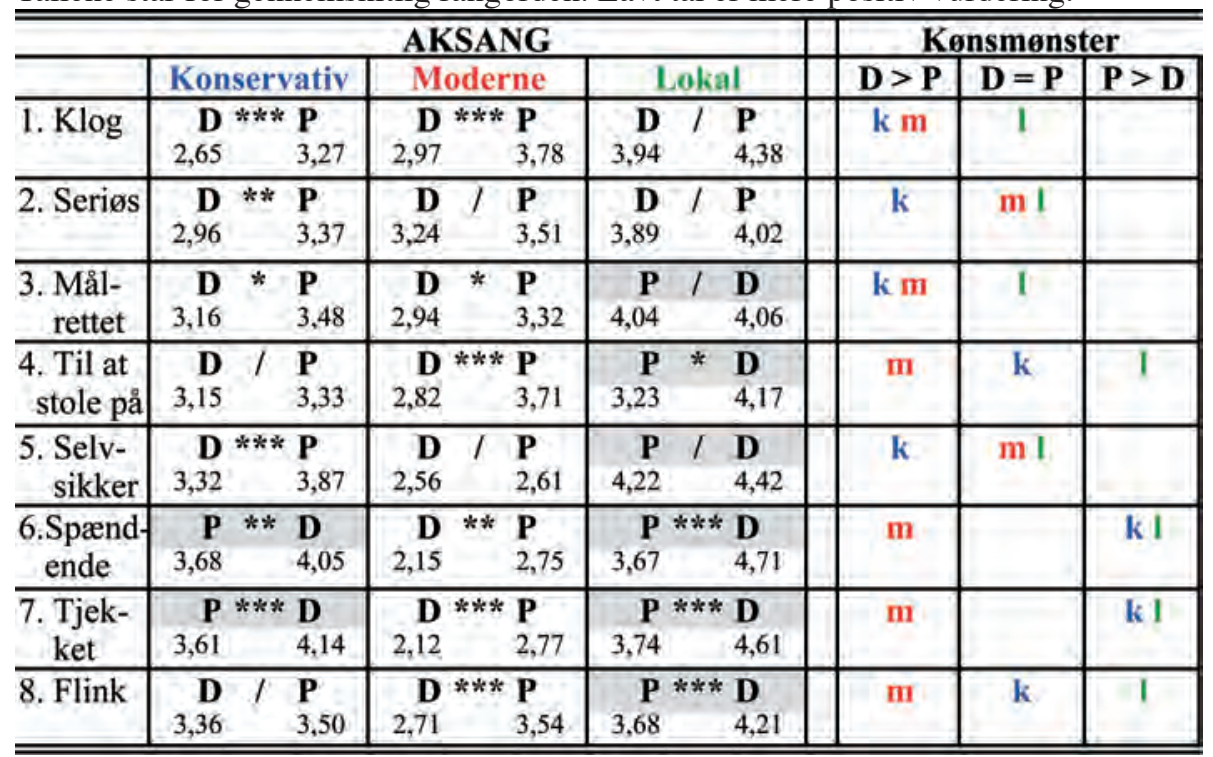

Wilcoxon Signed Pair Test: $* * *=\mathrm{p}<.001 * * \mathrm{p}<.01 *=\mathrm{p}<.05 \quad /=$ n.s.

Figur 8. Vissenbjerg: Vurdering af 'kønnet' (K/M/L)-variation.

Tallene står for gennemsnitlig rangorden. Lavt tal er mere positiv vurdering.

\begin{tabular}{|c|c|c|c|c|c|c|c|}
\hline & \multicolumn{4}{|c|}{ AKSANG } & \multicolumn{3}{|c|}{ Kønsmønster } \\
\hline & Konservativ & Moderne & Lokal & & $\mathbf{D}>\mathbf{P}$ & $\mathbf{D}=\mathbf{P}$ & $\mathbf{P}>\mathrm{D}$ \\
\hline 1. Klog & $\underset{2,45}{\mathbf{D}} * \underset{3,10}{\mathbf{P}}$ & $\underset{2,84}{\mathbf{D}} * * * \underset{3,78}{\mathbf{P}}$ & $\underset{3,74}{\mathbf{D}} \quad 1$ & $\begin{array}{l}\mathbf{P} \\
5,09\end{array}$ & $\mathrm{k} \mathrm{m}$ & 1 & \\
\hline 2. Seriøs & $\begin{array}{cll}\mathbf{D} & / & \mathbf{P} \\
2,72 & & 3,06\end{array}$ & 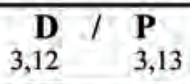 & $\mathbf{D}_{3,95}^{* * *}$ & $\begin{array}{l}\mathbf{P} \\
5,03\end{array}$ & I & $\mathrm{k} \mathrm{m}$ & \\
\hline $\begin{array}{l}\text { 3. Mål- } \\
\text { rettet }\end{array}$ & 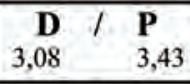 & $\begin{array}{rll}\mathbf{D} & / & \mathbf{P} \\
2,61 & & 3,07 \\
\end{array}$ & $\underset{3,95}{\mathbf{D}}$ ** & $\begin{array}{l}\mathbf{P} \\
5,03\end{array}$ & I & k m & \\
\hline $\begin{array}{l}\text { 4. Til at } \\
\text { stole på }\end{array}$ & $\underset{3,06}{\mathbf{D}} \quad / \quad \begin{array}{ll}\mathbf{P} \\
\end{array}$ & $\underset{2,94}{\mathbf{D}} * \underset{3,72}{\mathbf{P}}$ & $\underset{3,79}{\mathbf{D}} *$ & $\begin{array}{l}\mathbf{P} \\
4,18\end{array}$ & $\mathrm{~m} \mathrm{l}$ & $\mathbf{k}$ & \\
\hline $\begin{array}{l}\text { 5. Selv- } \\
\text { sikker }\end{array}$ & $\begin{array}{ccl}\underset{3,46}{\mathbf{D}} & / & \mathbf{P} \\
3,56\end{array}$ & $\begin{array}{ccl}\underset{2,47}{\mathbf{D}} & / & \mathbf{P} \\
& & \mathbf{2}, 88\end{array}$ & $\underset{3,68}{\mathbf{D} * * * 1}$ & $\begin{array}{l}\mathbf{P} \\
4,95\end{array}$ & I & $\mathrm{m} \mathrm{k}$ & \\
\hline $\begin{array}{l}\text { 6.Spænd- } \\
\text { ende }\end{array}$ & $\begin{array}{ccl}\mathbf{P} & / & \mathbf{D} \\
3,74 & & 4,01 \\
\end{array}$ & $\begin{array}{r}\mathbf{D} \\
2,37\end{array}$ & $\underset{3,84}{\mathbf{D}} / \mathbf{l}$ & $\begin{array}{l}\mathbf{P} \\
4,13\end{array}$ & $\mathrm{~m}$ & $k 1$ & \\
\hline $\begin{array}{l}\begin{array}{l}\text { 7. Tjek- } \\
\text { ket }\end{array} \\
\end{array}$ & \begin{tabular}{c|l|l|}
$\mathbf{P}$ & $/$ & $\mathbf{D}$ \\
3,69 & & 3,88 \\
\end{tabular} & $\begin{array}{r}\mathbf{D} \\
2,33\end{array}$ & \begin{tabular}{rl|} 
D & 1 \\
3,85 & \\
\end{tabular} & $\begin{array}{l}\mathbf{P} \\
4,15 \\
\end{array}$ & $\mathrm{~m}$ & kI & \\
\hline 8. Flink & \begin{tabular}{r|l}
$\underset{3,27}{\mathbf{D}} /$ & $\mathbf{P}$ \\
3,34 \\
\end{tabular} & 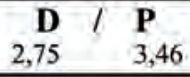 & $\begin{array}{c}\mathbf{D} \\
3,75\end{array}$ & $\begin{array}{l}\mathbf{P} \\
4,42\end{array}$ & & $\mathrm{k} \mathrm{m} \mathrm{I}$ & \\
\hline
\end{tabular}

Wilcoxon Signed Pair Test: $* * *=\mathrm{p}<.001 * * \mathrm{p}<.01 *=\mathrm{p}<.05 \quad /=$ n.s. 


\section{Tore Kristiansen}

\section{$\underline{\text { Næstved }}$}

I Næstved (Figur 7) er mønstret mht. den 'kønnede' (K/M)-variation som i København: Drenge kommer generelt bedst ud hvad enten de taler KONSERVATIVT eller MODERNE, med den samme undtagelse der siger at (K)-farvede Drenge er mere 6.kedelige og 7.utjekkede end (K)-farvede Piger.

Mht. LOKAL ser vi at Drenge kommer gennemgående dårligere ud end Piger ( $\mathrm{P}>\mathrm{D})$, især på de dynamiske værdier (se skalaerne 6-8). Drenge klarer sig relativt set bedre, dvs. lige så godt som Piger $(D=P)$, på de superiore værdier (se skalaerne 1-3).

\section{Vissenbjerg}

I Vissenbjerg (Figur 8), hvor der er langt færre informanter, er der også færre signifikante forskelle ${ }^{2}$. Men mønstret mht. den 'kønnede' (K/M)variation er det samme som i København og Næstved: Drenge vurderes generelt mere positivt end Piger, bortset fra at (K)-farvede Drenge er mere 6.kedelige og 7.utjekkede.

Til forskel fra Næstved vurderes også (L)-farvede Drenge gennemgående mere positivt end (L)-farvede Piger. Det kan dog bemærkes at den relative op- og nedvurdering af (D-1) og (P-1) i de to vurderingsdimensioner er som i Næstved: (D-1) står stærkere i superioritetsdimensionen end i dynamikdimensionen, og omvendt for (P-1).

\section{$\underline{\text { Odder }}$}

Odder (Figur 9) er som København, Næstved og Vissenbjerg mht. den 'kønnede' (K/M)-variation: Drenge vurderes gennemgående mere positivt end Piger, men (K)-farvede Drenge er klart mere 6.kedelige og 7.utjekkede, og kommer i det hele taget dårligere ud end (K)-farvede Piger på dynamikskalaerne (5-8).

Mht. LOKAL fremviser Odder den samme relative op- og nedvurdering af (D-1) og (P-1) som Næstved og Vissenbjerg: (D-1) står klart stærkest i superioritetsdimensionen, mens (P-1) klarer sig gennemgående bedre i dynamikdimensionen. 
Om betydningen af den senmoderne danske ...

Vinderup

Mønstret i Figur 10 tyder på de unge i Vinderup opererer med 'aksangog-køn'-stereotypier der afviger en del fra hvad vi foreløbig har fundet. På den ene side ser vi igen at (M)-farvning opvurderes som Drengesprog, men på den anden side ser vi en gennemgående opvurdering af både (K)- og (L)-farvning som Pige-sprog. Også den relative op- og nedvurdering af (D-1) og (P-1) i de to vurderingsdimensioner afviger fra hvad vi har set i Næstved, Vissenbjerg og Odder: Opvurderingen af (P-1) i forhold til (D-1) står stærkere i superioritetsdimensionen end i dynamikdimensionen.

Figur 9. Odder: Vurdering af 'kønnet' (K/M/L)-variation.

Tallene står for gennemsnitlig rangorden. Lavt tal er mere positiv vurdering.

\begin{tabular}{|c|c|c|c|c|c|c|c|c|c|}
\hline & \multicolumn{6}{|c|}{ AKSANG } & \multicolumn{3}{|c|}{ Kønsmønster } \\
\hline & Konser & vativ & Moder & & Loka & & $\mathbf{D}>\mathbf{P}$ & $\mathbf{D}=\mathbf{P}$ & $P>D$ \\
\hline 1. Klog & $\underset{2,64}{\mathbf{D}} * * *$ & $\begin{array}{l}\mathbf{P} \\
3,34\end{array}$ & $\underset{3,05}{\mathbf{D}} * * *$ & $\begin{array}{l}\mathbf{P} \\
3,81\end{array}$ & $\underset{3,33}{\mathbf{D}} /$ & $\begin{array}{l}\mathbf{P} \\
4,83\end{array}$ & $\mathrm{~km}$ & 1 & \\
\hline 2. Seriøs & $\underset{2,60}{\mathbf{D}} * * * *$ & $\begin{array}{l}\mathbf{P} \\
3,29\end{array}$ & $\underset{3,16}{\mathbf{D}} * *$ & $\begin{array}{l}\mathbf{P} \\
3,60\end{array}$ & $\underset{3,90}{\mathbf{D}} * * *$ & $\begin{array}{l}\mathbf{P} \\
4,45\end{array}$ & $\mathrm{~km} \mathrm{I}$ & & \\
\hline $\begin{array}{l}\text { 3. Mål- } \\
\text { rettet }\end{array}$ & $\underset{2,88}{\mathbf{D}} * * * *$ & $\begin{array}{l}\mathbf{P} \\
3,28\end{array}$ & $\underset{3,03}{\mathbf{D}} * *$ & $\begin{array}{l}\mathbf{P} \\
3,40\end{array}$ & $\underset{3,80}{\mathbf{D}} * * *$ & $\begin{array}{l}\mathbf{P} \\
4,61\end{array}$ & k m I & & \\
\hline $\begin{array}{l}\text { 4. Til at } \\
\text { stole pá }\end{array}$ & $\underset{2,97}{\mathbf{D}}$ ** & $\begin{array}{l}\mathbf{P} \\
3,32\end{array}$ & $\underset{2,93}{\mathbf{D}} * * *$ & $\begin{array}{l}\mathbf{P} \\
3,48\end{array}$ & $\underset{3,71}{\mathbf{D}} * * *$ & $\begin{array}{l}\mathbf{P} \\
4,60\end{array}$ & k m I & & \\
\hline $\begin{array}{l}\text { S. Selv- } \\
\text { sikker } \\
\end{array}$ & $\begin{array}{r}\mathbf{P} \\
3,22\end{array}$ & $\begin{array}{l}\text { D } \\
3,32 \\
\end{array}$ & $\underset{2,32}{\mathbf{D}} * * *$ & $\begin{array}{l}\mathbf{P} \\
2,85 \\
\end{array}$ & \begin{tabular}{rl|} 
D & $I$ \\
\end{tabular} & $\begin{array}{l}\mathbf{P} \\
4,71 \\
\end{array}$ & $\mathrm{~m}$ & k I & \\
\hline $\begin{array}{l}\text { 6.Spænd- } \\
\text { ende }\end{array}$ & $\mathbf{P}_{3,28}^{\mathbf{P}} * *$ & $\begin{array}{l}\text { D } \\
3,73\end{array}$ & ${ }_{2,21}^{\mathbf{D}}$ *** & $\begin{array}{l}\mathbf{P} \\
2,96\end{array}$ & $\underset{4,25}{\mathbf{D}} \quad /$ & $\begin{array}{l}\mathbf{P} \\
4,57\end{array}$ & $\bar{m}$ & 1 & k \\
\hline $\begin{array}{l}\text { 7. Tjek- } \\
\text { ket }\end{array}$ & $\mathbf{P}_{3,33}$ *** & $\begin{array}{l}\text { D } \\
4,04\end{array}$ & $\underset{2,07}{\mathbf{D}} * * *$ & $\begin{array}{l}\mathbf{P} \\
2,97\end{array}$ & $\begin{array}{r}\mathbf{P} \\
4,10\end{array}$ & $\begin{array}{l}\text { D } \\
4,49\end{array}$ & m & & k I \\
\hline 8. Flink & $\underset{3,46}{\mathbf{P}} \quad /$ & $\begin{array}{l}\text { D } \\
3,47\end{array}$ & $\underset{2,70}{\mathbf{D}} * * *$ & $\begin{array}{l}\mathbf{P} \\
3,21\end{array}$ & $\underset{3,66}{\mathbf{D}} * * *$ & $\begin{array}{l}\mathbf{P} \\
4,50\end{array}$ & m I & k & \\
\hline
\end{tabular}

Wilcoxon Signed Pair Test: $* * *=\mathrm{p}<.001 * * \mathrm{p}<.01 *=\mathrm{p}<.05 \quad /=$ n.s. 


\section{Tore Kristiansen}

Figur 10. Vinderup: Vurdering af 'kønnet' (K/M/L)-variation.

Tallene står for gennemsnitlig rangorden. Lavt tal er mere positiv vurdering.

\begin{tabular}{|c|c|c|c|c|c|c|c|}
\hline & \multicolumn{4}{|c|}{ AKSANG } & \multicolumn{3}{|c|}{ Kønsmønster } \\
\hline & Konservativ & Moderne & Loka & & $\mathbf{D}>\mathbf{P}$ & $\mathbf{D}=\mathbf{P}$ & $P>D$ \\
\hline I. Klog & 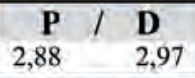 & $\underset{3,03}{\mathbf{D}} * * \mathbf{3}_{3,85}^{\mathbf{P}}$ & $\begin{array}{r}\mathbf{P} \\
3,89\end{array}$ & $\begin{array}{l}\text { D } \\
4,39\end{array}$ & $m$ & k & 1 \\
\hline 2. Seriøs & $\begin{array}{rll}\mathbf{P} & * * & \mathbf{D} \\
2,52 & & 3,12\end{array}$ & $\underset{3,07}{\mathbf{D}} * \mathbf{P}$ & $\underset{3,85}{\mathbf{P}} * * *$ & $\begin{array}{l}\text { D } \\
4,66\end{array}$ & $\mathbf{m}$ & & $\overline{\mathrm{kl}}$ \\
\hline $\begin{array}{l}\text { 3. Mål- } \\
\text { rettet }\end{array}$ & $\underset{2,81}{\mathbf{P}} * \boldsymbol{*} \quad \mathbf{3 , 4 9}$ & $\begin{array}{ccl}\underset{2,90}{\mathbf{D}} & / & \mathbf{P} \\
& & \\
3,48\end{array}$ & $\mathbf{P}_{3,71}$ *** & $\begin{array}{l}\text { D } \\
4,62\end{array}$ & & $\bar{m}$ & $\overline{\text { kl }}$ \\
\hline $\begin{array}{l}\text { 4. Til at } \\
\text { stole på }\end{array}$ & 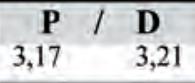 & $\begin{array}{rll}\underset{3,31}{\mathbf{D}} & / & \mathbf{P} \\
& & \\
, 42 & \end{array}$ & $\underset{3,48}{\mathbf{P}} * *$ & $\begin{array}{l}\text { D } \\
4,41\end{array}$ & & $\mathrm{~km}$ & 1 \\
\hline $\begin{array}{l}\text { 5. Selv- } \\
\text { sikker }\end{array}$ & $\begin{array}{c}\mathbf{P} \\
3,17\end{array}$ & $\begin{array}{r}\mathbf{D} \\
2,36\end{array} \quad \underset{2,81}{\mathbf{P}}$ & $\begin{array}{r}\mathbf{P} * * * \\
4,10\end{array}$ & $\begin{array}{l}\text { D } \\
4,86\end{array}$ & $m$ & & kl \\
\hline $\begin{array}{l}\text { 6.Spænd- } \\
\text { ende }\end{array}$ & $\underset{3,37}{\mathbf{P}} * * * \underset{4,32}{\mathbf{D}}$ & $\underset{2,18}{\mathbf{D}} * * \underset{2,53}{\mathbf{P}}$ & $\begin{array}{rl}\mathbf{P} & \mathbf{1} \\
4,20 & \end{array}$ & $\begin{array}{l}\text { D } \\
4,40\end{array}$ & $\mathrm{~m}$ & I & k \\
\hline $\begin{array}{l}\text { 7. Tjek- } \\
\text { ket }\end{array}$ & 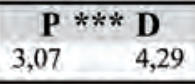 & $\begin{array}{ccl}\mathbf{D} & / & \mathbf{P} \\
2,36 & & 2,84 \\
\end{array}$ & $\underset{4,10}{\mathbf{P}}$ * & $\begin{array}{l}\text { D } \\
4,34\end{array}$ & & m & kl \\
\hline 8. Flink & $\begin{array}{lll}\mathbf{D}_{3,46} & / & \mathbf{P} \\
& 3,47 \\
\end{array}$ & 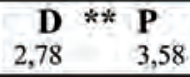 & $\begin{array}{r}\mathbf{P} \\
3,66\end{array}$ & $\begin{array}{l}\text { D } \\
4,05\end{array}$ & $\mathrm{~m}$ & k I & \\
\hline
\end{tabular}

Wilcoxon Signed Pair Test: $* * *=\mathrm{p}<.001 * * \mathrm{p}<.01 *=\mathrm{p}<.05 \quad /=$ n.s.

\subsection{Taler-kønnets betydning: Opsummering og diskussion}

Figur 11 er en opsummering af de kønsmønstre vi har analyseret frem i Figurerne 6-10. Hvid celle betyder at informantudvalget vurderede Drenge mere positivt end Piger; grå celle betyder at informantudvalget vurderede Piger mere positivt end Drenge. Kryds i cellen angiver at forskellen blev testet statistisk signifikant.

Figur 11: Vurdering af 'kønnet' (K/M/L)-variation. Alle 5 samfund

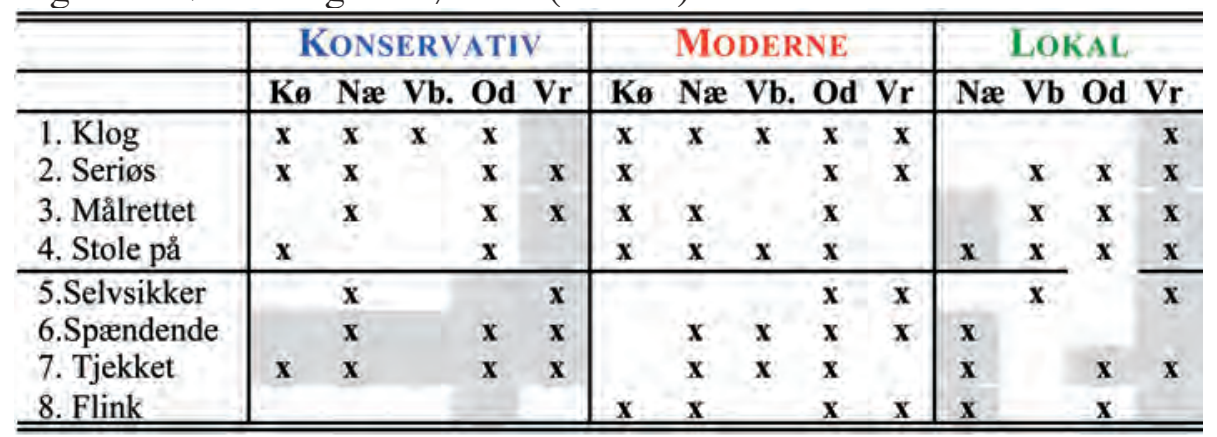

hvid celle: $\mathrm{D}>\mathrm{P}$; grå celle: $\mathrm{P}>\mathrm{D} ; \mathrm{x}$ : forskellen er signifikant 
Om betydningen af den senmoderne danske ...

I Figur 12-14 er resultaterne for de 'kønnede' aksanger fremstillet i kurveform. De vigtigste træk i mønstret kan opsummeres som følger:

- (K)-farvning vurderes højere hos Drenge end hos Piger når det gælder de 'superiore' værdier (med Vinderup som undtagelse), men mere negativt mht. de 'dynamiske' værdier. Især den relative nedvurdering af (K)-Drenge som 'kedelige' og 'utjekkede' er gennemgående og generel. (Sammenlign blå stiplet kurve med blå hel linje i Figur 12.)

- Det gælder generelt, i begge vurderingsdimensioner og i alle samfund, at (M)-farvning vurderes mere positivt som Drenge-sprog end som Pige-sprog. (Sammenlign rød stiplet kurve med rød hel linje i Figur 13.)

- (L)-farvning kommer bedst ud som Drenge-sprog i Vissenbjerg og Odder, men som Pige-sprog i Vinderup (på alle skalaer) og Næstved (på dynamikskalaer især). (Sammenlign grøn stiplet kurve med grøn hel linje i Figur 14.)

Figur 12. Vurderinger af den 'kønnede' (K)-variation i hvert af samfundene og totalt

$$
\text { - - -(D-k) - (P-k) }
$$

\section{KØBENHAVN}

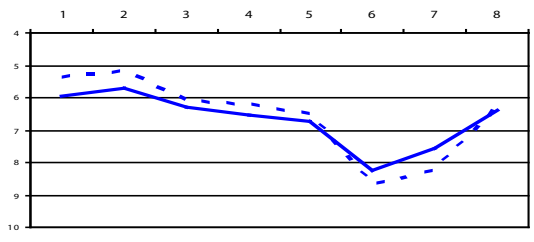

VISSENBJERG

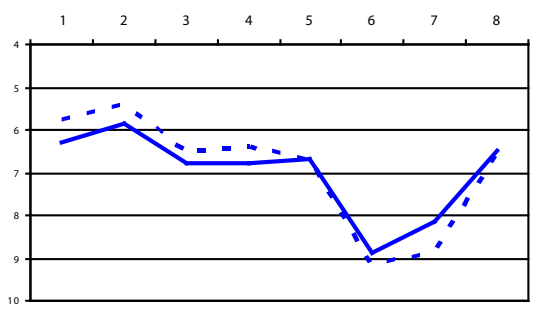

\section{NASTVED}

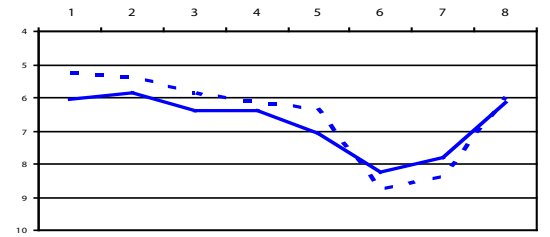

\section{ODDER}

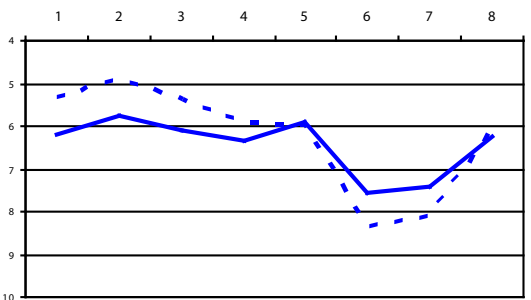


VINDERUP

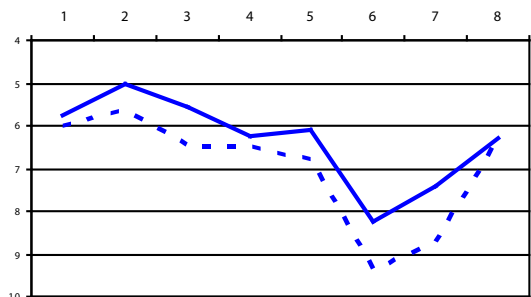

\section{TOTAL}

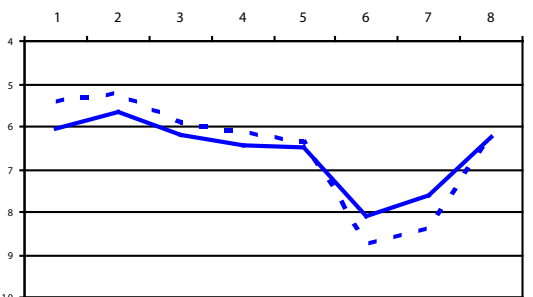

Tallene 4-10 på værdiaksen er fra den 'skala' der fremkommer når vi sammenlægger 2 stemmers værdier på skalaer med 7 trin; den får minimumsværdi 2 , maksimumsværdi 14, og midterværdi 8. Aksangernes gennemsnit på vurderingsskalaerne fås ved at dividere med 2 . Lav værdi (øverst på aksen) er mere positiv vurdering.

Tallene 1-8 på kategoriaksen står for personlighedstrækkene (se Figur 4).

Figur 13. Vurderinger af den 'kønnede' (K)-variation i hvert af samfundene og totalt

\section{KØBENHAVN}

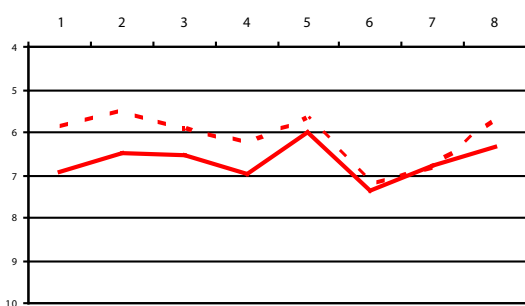

$$
\text { - - -(D-m) - (P-m) }
$$

\section{NESTVED}

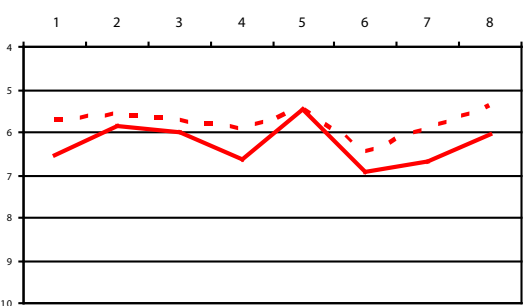

VISSENBJERG

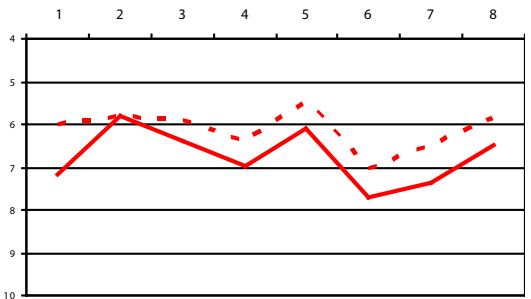

\section{ODDER}

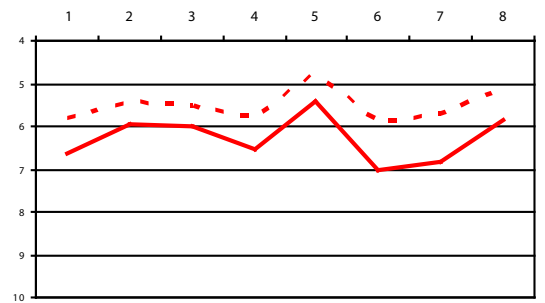




\section{VINDERUP}

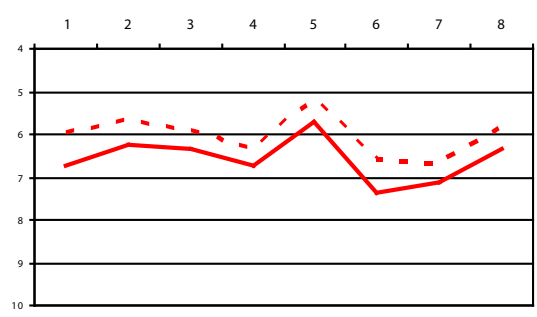

\section{TOTAL}

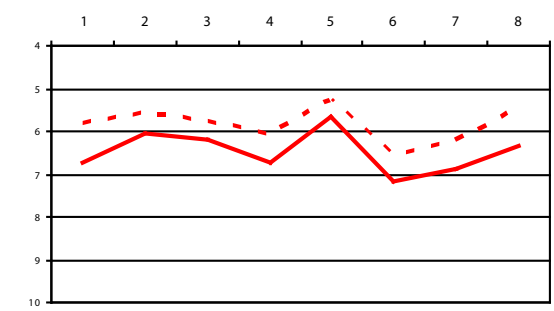

Tallene 4-10 på værdiaksen er fra den 'skala' der fremkommer når vi sammenlægger 2 stemmers værdier på skalaer med 7 trin; den får minimumsværdi 2 , maksimumsværdi 14, og midterværdi 8. Aksangernes gennemsnit på vurderingsskalaerne fås ved at dividere med 2 . Lav værdi (øverst på aksen) er mere positiv vurdering.

Tallene 1-8 på kategoriaksen står for personlighedstrækkene (se Figur 4).

Figur 14. Vurderinger af den 'kønnede' (L)-variation i hvert af samfundene og totalt

$$
\text { - - -(D-1) -(P-1) }
$$

\section{NFSTVED}

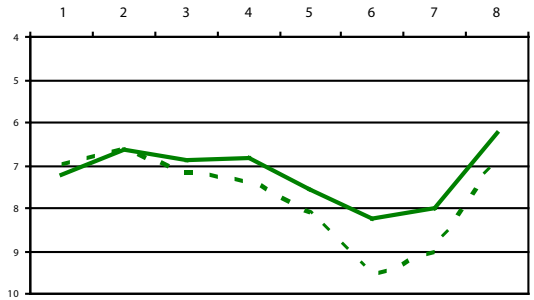

VISSENBJERG

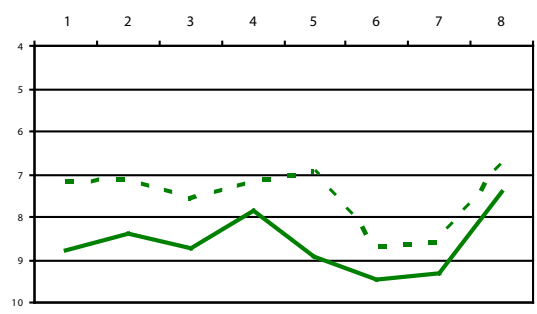

\section{ODDER}

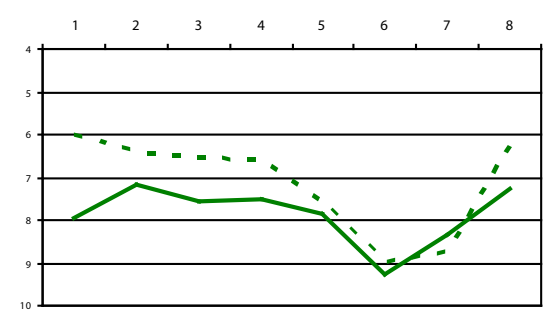


VINDERUP

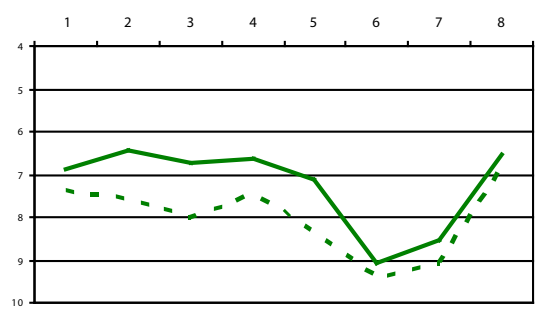

TOTAL

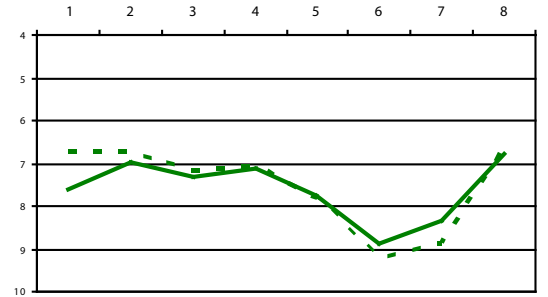

Tallene 4-10 på værdiaksen er fra den 'skala' der fremkommer når vi sammenlægger 2 stemmers værdier på skalaer med 7 trin; den får minimumsværdi 2, maksimumsværdi 14, og midterværdi 8. Aksangernes gennemsnit på vurderingsskalaerne fås ved at dividere med 2. Lav værdi (øverst på aksen) er mere positiv vurdering.

Tallene 1-8 på kategoriaksen står for personlighedstrækkene (se Figur 4).

Teoretisk set kan vurderingerne af de 'kønnede' aksanger give tre slags mønstre. To af disse er ensbetydende med at der ikke findes betydningsfulde kønsrelaterede stereotypier knyttet til den sproglige variation som de tre aksanger repræsenterer. Det ville for det første gælde hvis der overhovedet ikke var nogen forskel på hvordan Drenge-versioner og Pige-versioner af aksangerne blev vurderet. Men det ville også gælde hvis der var forskel, og denne forskel var den samme for alle tre aksangers vedkommende. Det ville betyde at kønsforskellen var af betydning, og at aksangforskellen ikke var. Det er imidlertid det tredje slags mønster vi har fundet: Der er forskel på hvordan Drenge-versioner og Pige-versioner af aksangerne vurderes, og forskellen er ikke den samme. Dermed står vi over for spørgsmålet om hvilken rolle (hvilken betydning) de tre aksanger har i konstruktionen af kønsidentitet blandt unge mennesker forskellige steder i dagens Danmark.

\section{MODERNE: Vurderingen af (D-m) og (P-m)}

Vi sætter først fokus på MODERNE. (M)-farvet sprog er vurderet mere positivt som Drenge-sprog end som Pige-sprog $(\mathrm{D}>\mathrm{P})$ - på alle skalaer, i alle samfund. Det vil vi tillade os at kalde en interessant påvisning af en stereotyp køn/aksang-association.

Hvis vi nu vil fors $\varnothing$ ge at forklare, sker det formentlig bedst ved at inddrage resultater baseret på andre datatyper, fx data fra interview med de unge. Men indtil videre har vi ikke analyser af andre datatyper der kan kaste lys over hvorfor (M)-farvning generelt giver Drenge mere kredit end Piger. Så vores spæde forklaringsforsøg her må bestå i at sammenholde den eksperimentelt erhvervede viden om hvad (K/M/L)variationen betyder socialt, med almen (stereotyp) viden om hvad det 


\section{Om betydningen af den senmoderne danske ...}

vil sige at være hhv. "en rigtig dreng" og en "rigtig pige" - og på det grundlag fundere over (D>P)-mønstrets absolutte dominans.

Lad os begynde med at rekapitulere at den relative opvurdering af (M)-farvet sprogbrug først og fremmest findes på dynamikskalaerne. Det er en fordel at tale (M)-farvet hvis man vil fremstå som 'selvsikker', 'spændende', 'tjekket' og 'flink' (se Figur 4). Dernæst synes det rimeligt at foreslå, med basis ikke blot i egne stereotypier, at 'konformitet versus nonkonformitet' traditionelt har stået stærkt i de almene forestillinger om forskellen på piger og drenge. En rigtig pige er 'pæn'. En rigtig dreng er lidt 'fræk' og 'uartig'.

Disse vores forestillinger om piger og drenge lever naturligvis ikke afsondret fra vores forestillinger om sprogbrug. Så øvelsen her fortsætter med at fundere over hvordan de to sæt af forestillinger skal kobles. Det bliver spekulativt, men jeg fornemmer at min egen begrebsverden er ordnet (stereotypificeret) sådan at det er det 'frække og uartige' der hænger tættest sammen med det 'selvsikre, spændende, tjekkede og flinke'. Umiddelbart kan man måske indvende at 'flink' da snarere må høre sammen med 'pæn'. Men her skal vi huske på at den modsatte ende af skalaen hedder 'usympatisk' (se skalaerne i Figur 3). I min begrebsverden tror jeg egentlig ikke at "en rigtig dreng" er usympatisk. Tværtimod er der noget forsonende 'flinkt' ved sådan en. Han er "en rigtig dreng", siger vi (hvis vi da ikke siger "boys will be boys"), og smiler overbærende på anerkendende vis.

Bemærk at det der siges her, ikke er at (M)-farvede Drengestemmer vurderes positivt mht. dynamiske værdier. Ræsonnementet er et forsøg på at forklare det generelle (D>P)-mønster, som jo også gælder mht. superiore værdier. Forklaringen er at stereotype positive værdier knyttet til (M)-farvning er associativt forbundet med stereotype positive værdier knyttet til drenge-identitet. Denne associative kobling findes hos unge over alt i landet. Hvordan det kan lade sig gøre, er et højst interessant spørgsmål. Det er sandsynligt at svaret skal søges i fælles erfaringer med 'køn-og-aksang' i den moderne offentlighed: de landsdækkende lydmedier.

\section{KonSERVATIV: Vurderingen af (D-k) og (P-k)}

Vi fokuserer så på KONSERVATIV. Når vi finder at de positive superioritetsværdier ('klog', 'seriøs', 'målrettet', 'til at stole på') i højere grad associeres med (D-k) end med (P-k), virker det umiddelbart som et forbavsende fund - til dels fordi det igen og igen er blevet påvist i sociolingvistiske undersøgelser at piger/kvinder taler mere 'standardnært' 


\section{Tore Kristiansen}

(dvs. (K)-farvning i vores sammenhæng) end drenge/mænd - og ikke mindst fordi dette forhold ofte ses som udtryk for at "det svage køn" s $\varnothing$ ger at styrke sin sociale position gennem opslutning om samfundsværdier af 'superioritetstypen'. Det er denne norm-konformitet der giver os de "pæne piger".

Når det så alligevel er (D-k) der associeres stærkest med værdier som 'klog, seriøs, målrettet' og 'pålidelig', er grunden formentlig netop den at det er drenge/mænd der traditionelt står stærkest og når længst i den offentlighed hvor 'superioritetsværdierne' står højt i kurs: skole og erhvervsliv. Bagsiden af den medalje er at der ikke er noget 'spændende' og 'tjekket' ved en (K)-sproget Dreng. Det 'ved' de unge hele vejen fra København til Vinderup.

I det hele taget virker det næppe overraskende på ret mange at det lige netop er på skalaerne 'tjekket-utjekket' og 'spændende-kedelig' at (D-k) klarer sig dårligst. Når det ikke virker overraskende, må det igen være fordi begreber som 'tjekket' og 'spændende' hænger forskelligt sammen med almene forestillinger om hvad det vil sige at være "en rigtig pige" og "en rigtig dreng". Eftersom (K)-farvning associeres med 'intelligens', 'seriøsitet', 'målrettethed' og 'pålidelighed' (se Figur 4) værdier og normer der for mange sikkert står for konformitet - vil vores fordomme (forventninger) om sammenhængen mellem køn og konformitet placere (K)-farvede Drenge som 'utjekkede' og 'kedelige'.

Her skal vi lige huske på at også (K)-farvede Piger er 'utjekkede' og 'kedelige' sammenlignet med unge der taler (M)-farvet, uanset køn (se Figur 13). Så konklusionen skal formuleres sådan: Hvis man $p a ̊$ trods af $(\mathrm{K})$-farvet sprogbrug gerne vil fremstå som 'tjekket' og 'spændende', eller mere generelt som en 'dynamisk' person, er projektet mere håbløst for drenge end for piger. Det gælder overalt, for den umiddelbare vurdering baseret på stereotypier.

LOKAL: Vurderingen af (D-1) og (P-1)

Hvad LOKAL angår, er billedet mere broget idet den generelle nedvurdering (i forhold til KONSERVATIV og MODERNE) er stærkest mht. Drenge i Vinderup og Næstved, mht. til Piger i Vissenbjerg og Odder (se Figur 14). At sammenlægge til et total-billede giver derfor mindre mening.

Et interessant fællestræk ved vurderingen af den 'kønnede' (L)farvning skal dog bemærkes. Uanset hvordan (L)-Piger og (L)-Drenge ligger i forhold til hinanden i absolutte værdier på de 8 skalaer, så gælder det $\mathrm{i}$ alle samfund (undtagen Vinderup, hvor forholdet er omvendt) at (L)-Drenge kommer relativt set bedre ud mht. de 'superiore' værdier 
Om betydningen af den senmoderne danske ...

end mht. de 'dynamiske' værdier (se kurveforløbene i Figur 14). I så henseende ligner de (L)-tilknyttede 'køn-og-aksang'-stereotypier de (K)-tilknyttede (se kurveforløbene i Figur 12).

Den substantielt interessante udlægning af det mere brogede billede ville naturligvis være at den 'kønnede' (L)-farvning betyder noget forskelligt fra sted til sted - og altså indgår på forskelligt vis i de sociale identifikationsprocesser hvori unge danskere skaber sig selv. Det ville være et overordentlig interessant fund, for det ville indebære at der findes et hjørne af det ideologiske univers vi undersøger, som ikke er styret fra København. Der er imidlertid et metodologisk 'men': Eftersom de 4 (L)-stemmer var forskellige fra sted til sted (til forskel fra (K)- og (M)-stemmerne som var de samme), kan det ikke udelukkes at det mere brogede billede mht. LOKAL, skyldes (L)-farvningens karakter - altså at (L)-farvningen af hhv. Pige-stemmer og Drenge-stemmer kan have været noget anderledes i Vinderup og Næstved end i Vissenbjerg og Odder.

Når det er sagt, skal det tilføjes at vurderingen af KONSERVATIV i Vinderup kan inddrages i argumentationen her. Den vurdering kunne nemlig tyde på at det ikke med nødvendighed er sådan at unge danskeres 'køn-og-aksang'-stereotypier bare er kopier af hvad vi finder i København. Vinderup afviger fra de andre samfund ved at (K)-Piger vurderes mere positivt end (K)-Drenge i superioritetsdimensionen (se Figur 11 og 12, skalaerne 1-4). Dermed synes (K)-farvning af sprogbrugen at indgå i de unges (re-)konstruktion af kønsrelaterede sociale værdier og vurderinger på en anden måde i Vinderup end i de andre samfund. Forhåbentlig vil vi kunne belyse problemstillingen bedre ved at inddrage andre typer af data. - På samme måde kan vi håbe at andre data og analyser vil kunne bidrage til bedre forståelse af hvorfor 'kønnede' (L)-aksanger vurderes så forskelligt som tilfældet er.

\section{Noter}

1 Jeg skriver Pige og Dreng med stort førstebogstav når det drejer sig om stemmerne der blev brugt i masketesten (dvs. den brugte dataindsamlingsmetode som omtales i den videre tekst).

2 Selv om forskellene ikke i samme grad som i København og Næstved er testet statistisk signifikante, kan vi faktisk udtale os med større - ja, fuldstændig - sikkerhed om resultaterne fra Vissenbjerg hvad stedets 9.klasseelever angår. Signifikans- 
testning drejer sig om at beregne risikoen for at tage fejl når man generaliserer fra et fund i et udvalg af informanter til en større population. (Vi siger at acceptabel risiko skal være under $5 \%$, udtrykt $\mathrm{p}<0,05$.) Hvis vores population er 9.klasseeleverne i de 5 samfund, giver det god mening at signifikansteste i København og Næstved idet vi her har samlet data ikke fra populationen men fra udvalg. De tre andre steder, i Vissenbjerg, Odder og Vinderup, deltog alle 9.klasseelever, så vi kan uden nogen form for risiko for at tage fejl sige at vores resultat gælder. Det giver altså ikke mening at signifikansteste disse steder med mindre vi betragter 9.klasseeleverne som repræsentative udvalg fra en eller anden form for større population. Det kunne være et bredere alderssegment ( $\mathrm{fx}$ de 13-17-årige). Men det er også muligt at argumentere for at vores 4 lokalsamfund er repræsentative for forskellige samfundstyper, og at signifikanstestningen gælder generaliseringskraften i forhold til alle samfund af samme type. (Der er naturligvis kun ét København.) Eller vi kan argumentere for at vores 5 samfund tilsammen er repræsentative for det danske samfund som helhed. I så tilfælde vil det være forskelle i totalresultatet (alle 5 samfund lagt sammen) der skal testes for signifikans. Vi skal lade den problematik ligge her og blot understrege at resultaterne fra Vissenbjerg, Odder og Vinderup omhandler samtlige 9.klasseelever.

\title{
Litteratur
}

http://dgcss.hum.ku.dk/

Kristiansen, Tore (2009). The macro-social meanings of late-modern Danish accents. Acta Linguistica Hafniensia 41: 167-192. [specialnummer om arbejdet ved DGCSS, redigeret af Centerleder Frans Gregersen].

Maegaard, Marie (2005). Language attitudes, norm and gender. Acta Linguistica Hafniensia 37: 55-80.

\author{
Tore Kristiansen \\ Professor \\ Nordisk Forskningsinstitut \\ Københavns Universitet \\ tore.kristiansen@hum.ku.dk
}

